culty, judging by the numerous droppings and feather sheaths in the nest bowl.

The Goldfinch is an abundant nesting species in the orchards of the Okanagan valley. This is the first occurrence of such an unusual form of mortality in about 30 Goldfinch nests observed this summer.

\section{FIRST RECORD OF LARK BUNTING AND LARK SPARROW AT SPIRIT LAKE, SASKATCHEWAN}

by William Anaka, Gorlitz

On June 2, 1967 a male Lark Bunting (Calamospiza melanocorys) flushed in front of the tractor while I was driving across a native prairie meadow, thereby establishing a new record for Spirit Lake. Dr. C. Stuart Houston's check-list of Birds of the Yorkton district (1949) lists the nearest previous observation from Melville, approximately 50 miles to the south-southwest.

While at the Saskatchewan Natural History Society's summer meeting at Swift Current in June, 1967, I noted that the Lark Bunting was the most conspicuous bird species of the area, as we drove through miles and miles of male buntings, all busily singing and displaying.

Four days later, on June 6, 1967, a new species was added to the birds of the Yorkton district when a Lark Sparrow (Chondestes grammacus) spent an afternoon in our farmyard, alternately feeding and singing. Its conspicuous markings and large size alerted me to its presence as it fed near a number of House Sparrows. The song was even more distinctive, a variety of warbles and trills, occasionally interspersed with a loud buzz. It was noted again on June 20 and June 23 in a nearby pasture field where it sang repeatedly from several locations and behaved as if on territory, at one time aggressively routing a cowbird that ventured near. Lack of additional observations would indicate that it failed to attract a mate and eventually moved on.

In conversation with Dr. Stuart
Houston I have verified that these two birds are new records for these districts.

\section{COWBIRD EGG IN CROW NEST}

by David R. M. Hatch, 736 - 15th St., Brandon, Manitoba

On June 15, 1967 I found a Common Crow nest one-half mile east of the town of Oak Lake, Manitoba, and proceeded to climb the aspen poplar tree in which it was located in order to check the nest contents. To my utter amazement the nest contained a Brown-headed Cowbird egg besides the clutch of five crow eggs. Unfortunately, this nest had been destroyed when I returned to visit it one week later (June 22). The nest site was on the edge of a willow-aspen bluff covering about one-half acre. This was one of a series of bluffs growing in a low area in a heavily grazed pasture. To my knowledge, this is the first occurrence of a cowbird egg being found in a nest of a crow.

\section{ERRATUM}

In the listing of Black-crowned Night Heron recoveries on page 112 of the September 1967 issue, incorrect banding and recovery dates were given for George Lang's seventh Night Heron, shot in Vera Cruz, Mexico. It was banded June 20, 1925 and shot in mid-November of the same year. (The data from the bird above were inadvertently repeated in error).

\section{CHRISTMAS BIRD COUNT 1967}

In your report, list the numbers of each species seen on the $\mathrm{ONE}$ BEST DAY between December 20 and January 1 (inclusive). In addition, list other species (number of individuals and date seen) between December 20 and January 1. Send reports as soon as possible to

MRS. MARY HOUSTON, 863 University Drive, Saskatoon 